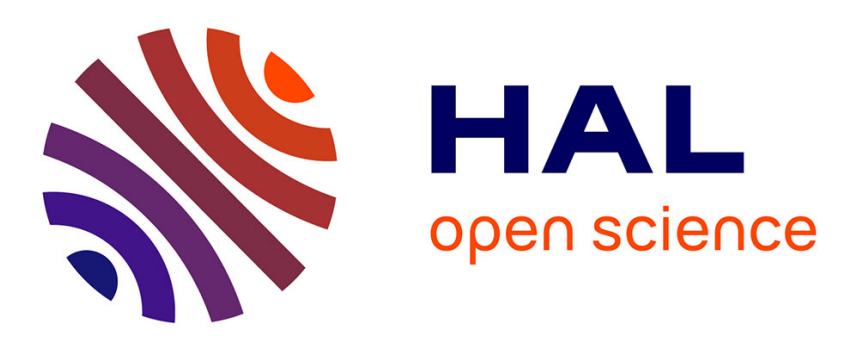

\title{
Survey of the anticoccidial feed additive nicarbazin (as dinitrocarbanilide residues) in poultry and eggs
}

Martin Danaher

\section{To cite this version:}

Martin Danaher. Survey of the anticoccidial feed additive nicarbazin (as dinitrocarbanilide residues) in poultry and eggs. Food Additives and Contaminants, 2007, 25 (01), pp.32-40. 10.1080/02652030701552956 . hal-00577312

\section{HAL Id: hal-00577312 \\ https://hal.science/hal-00577312}

Submitted on 17 Mar 2011

HAL is a multi-disciplinary open access archive for the deposit and dissemination of scientific research documents, whether they are published or not. The documents may come from teaching and research institutions in France or abroad, or from public or private research centers.
L'archive ouverte pluridisciplinaire HAL, est destinée au dépôt et à la diffusion de documents scientifiques de niveau recherche, publiés ou non, émanant des établissements d'enseignement et de recherche français ou étrangers, des laboratoires publics ou privés. 


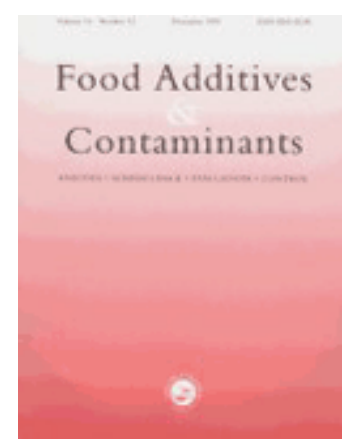

\section{Survey of the anticoccidial feed additive nicarbazin (as dinitrocarbanilide residues) in poultry and eggs}

\begin{tabular}{|c|c|}
\hline Journal: & Food Additives and Contaminants \\
\hline Manuscript ID: & TFAC-2007-039.R1 \\
\hline Manuscript Type: & Original Research Paper \\
\hline $\begin{array}{l}\text { Date Submitted by the } \\
\text { Author: }\end{array}$ & 26-Jun-2007 \\
\hline Complete List of Authors: & Danaher, Martin; Teagasc, Food Safety \\
\hline Methods/Techniques: & $\begin{array}{l}\text { Chromatography - HPLC, Chromatography - LC/MS, Screening - } \\
\text { biosensor, Survey }\end{array}$ \\
\hline Additives/Contaminants: & Residues \\
\hline Food Types: & Animal products - meat, Eggs \\
\hline
\end{tabular}

\section{SCHOLARONE \\ Manuscripts}




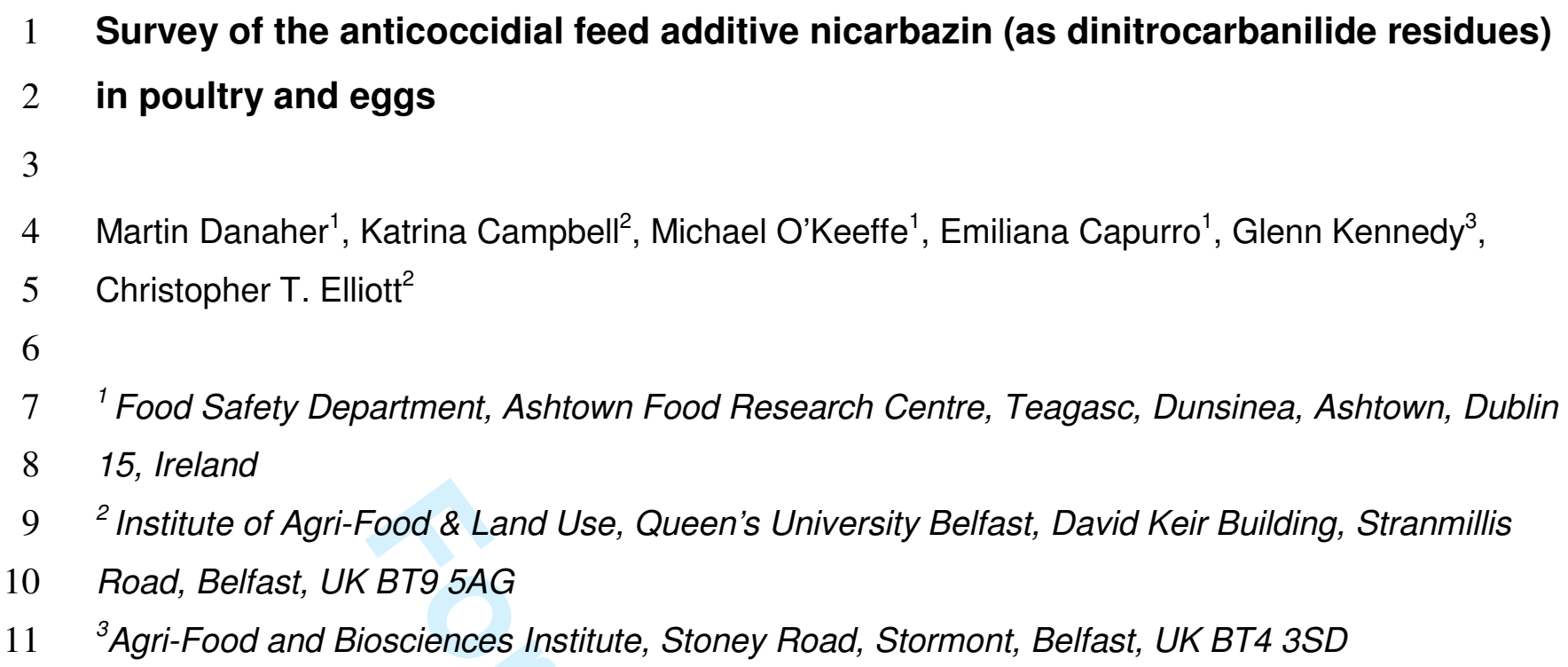

A survey was carried out on the occurrence of dinitrocarbanilide (DNC) the marker residue for nicarbazin, in poultry produced in Ireland during the years 2002 to 2004 . Liver $(n=736)$ and breast muscle samples $(n=342)$ were tested. DNC residues were found in $40 \%$ and $26 \%$ of liver and breast muscle samples at levels greater than 12.5 and $5 \mu \mathrm{gg}^{-1}$, respectively. DNC residues were found at $>200 \mu \mathrm{g} \mathrm{kg}^{-1}$ in 12 and $0 \%$ of liver and muscle samples, respectively. Samples of breast muscle $(n=217)$ imported from 11 countries were also tested for DNC residues. A lower incidence of DNC residues (6\%) was found in imported breast muscle. Egg samples $(n=546)$ were tested and DNC residues were found in nine samples, with levels ranging between 14 and $122 \mu \mathrm{kg}^{-1}$. Analysis of poultry, carried out as part of official food inspection in the period 2004 to 2006, indicated a reduction in the number of broiler liver samples containing DNC at $>200 \mu \mathrm{g} \mathrm{kg}^{-1}$, to approximately $7 \%$. Low levels of DNC residues continue to be found in $<2 \%$ of egg samples.

\section{Introduction}

Nicarbazin is an equimolar mixture of $4,4^{\prime}$-dinitrocarbanilide (DNC) and 2-hydroxy-4,6dimethylpyrimidine (HDP). It is administered to poultry in feed for the prophylactic treatment of coccidiosis. Coccidiosis is an infectious disease caused by a microscopic protozoan parasite, which damages the intestinal tract of the bird, causing illness and sometimes death. Intensively 
1 reared broilers are particularly susceptible to the disease, owing to the warm and humid conditions 2 of broiler houses. The disease is not as common when birds are raised under extensive conditions. 3 The licence for feed premixes containing nicarbazin as a single active ingredient was withdrawn 4 under Commission Regulation 2205/2001/EC [Anon. 2001]. Nicarbazin continues to be legally 5 marketed at levels of $40-50 \mathrm{mg} \mathrm{kg}^{-1}$, together with the feed additive ionophore narasin, as the 6 combined product Maxiban® [Anon. 2007].

Nicarbazin is classified as a feed additive and not as a veterinary drug. No maximum 8 residue limits (MRLs) have been set for nicarbazin in the European Union (EU). Nicarbazin 9 depletion studies that have been carried out in broilers show that DNC is a more persistent residue 10 than HDP in edible tissues (Porter and Gilfillan, 1955). The FAO/WHO Joint Expert Committee on 11 Food Additives (JECFA) established an MRL of $200 \mu \mathrm{gg}^{-1}$ for DNC, as the marker residue, in 12 edible tissue (liver and meat) [Wells 1999]. The JECFA MRL for DNC has been adopted as the 13 action limit by regulatory authorities in the Republic of Ireland and in the UK. Liver samples are 14 tested for DNC residues in monitoring programmes on the island of Ireland as this tissue tends to 1 contain higher residue concentrations than muscle. No MRL has been defined for DNC in eggs because nicarbazin is not approved for use in laying hens. An action level of $100 \mu \mathrm{kg}^{-1} \mathrm{DNC}$ in eggs has been adopted in the UK [Veterinary Residues Committee 2006].

The presence of DNC residues was first reported in poultry products nearly 20 years ago [De Giovanni et al. 1989, Oishi and Oda 1989]. Since then DNC residues have been reported in egg and liver samples tested in The Netherlands, UK, Italy and Ireland [Vertommen et al. 1989, 21 Veterinary Residues Committee 2006, Gallo and Serpe 1997, O'Keeffe et al. 2005]. A number of studies have been carried out to identify the factors that may contribute to the presence of DNC residues in eggs and edible tissues, such as feed contamination [Cannavan and Kennedy 2000, Cannavan et al. 2000, McEvoy et al. 2003], withdrawal period [Cannavan and Kennedy 2000] and faecal recycling [Cannavan and Kennedy 2000, Penz et al. 1999]. The relationship between levels of nicarbazin in contaminated feed and corresponding levels of DNC residues in eggs and liver has proved useful in identifying trigger limits for nicarbazin as a contaminant in non-medicated feed. DNC residues in eggs can be attributed to poor practices at feedmills because nicarbazin is not licensed for use in laying hens. However, control of DNC residues in broiler tissues is more 
1 complex than eggs because nicarbazin is widely applied to broilers and several on-farm factors 2 that may contribute to residues. The contribution of on-farm factors to the DNC residues in broiler 3 tissues has been described in more detail elsewhere [O'Keeffe et al 2006a]. In the study reported here, DNC contamination of tissues and eggs has been investigated 5 in an integrated study across Ireland. Three surveys were organised to investigate the presence of 6 DNC in eggs, liver and muscle between the years 2002 and 2004. In addition, a study on DNC 7 residues in samples of imported poultry meat was undertaken.

9 Experimental

10 Apparatus, chemicals and reagents

$114,4^{\prime}$-dinitrocarbanilide (DNC) standard material was from Sigma-Aldrich (St. Louis, MO, USA). The 12 deuterium-labelled internal standard (d8-DNC) was custom synthesised by Quchem (Queen's 13 University, Belfast). Acetonitrile, methanol, dimethylformamide, water (all HiPerSolv grade), 14 dimethylsulphoxide and $n$-hexane (Analar grade) were obtained from BDH (Merck, Poole, Dorset, 15 UK). Cyclohexane (Pestican grade) was obtained from Labscan (Dublin, Ireland). DNC standard 16 stock solution (1 mg ml${ }^{-1}$ ) was prepared in dimethylsulphoxide (Biacore and HPLC assays) and 17 DNC and d8-DNC standard stock solutions $\left(1 \mathrm{mg} \mathrm{ml}^{-1}\right)$ in dimethylacetamide (LC-MS/MS). The 18 biosensor and HPLC standard solutions were prepared every 3 months and were stored in amber 19 glass vials at room temperature in the dark preventing their solidification. LC-MS/MS standard 20 solutions were stored at $4^{\circ} \mathrm{C}$ and were stable for at least one month. The optical SPR Biosensor

system (Biacore ${ }^{T M} Q$ ) was obtained from Biacore ${ }^{T M}$ (Uppsala, Sweden). Sensor chips (CM5), HBSEP (0.01 M HEPES pH 7.4, 0.15 M NaCl, 3 mM EDTA, 0.005\% v/v Surfactant P20) buffer and an amine coupling kit were purchased from Biacore ${ }^{\mathrm{TM}}$. Biacore control software, version 3.1, was used 24 for instrument operation and BIA evaluation software, version 3.0, for data handling. Chip surfaces 25 were prepared by immobilisation of a DNC mimic, glutamic acid (1-glutamic acid-( $p$-nitroanilide)), 26 which was obtained from Sigma (Poole, Dorset, UK). A DNC polyclonal antibody (R555) was used 27 for the biosensor assay. Production of the DNC antibody are described in detail elsewhere 
1 [Connolly et al. 2002]. Bond Elut ${ }^{\mathrm{TM}}$ cartridges $\left(\mathrm{C}_{18}, 500 \mathrm{mg}, 3 \mathrm{ml}\right)$ were from Varian (Harbor City, 2 CA, USA).

4 Biosensor screening assays

5 Egg and liver samples were screened using a Biacore ${ }^{\mathrm{TM}}$ Biosensor assay [McCarney et al. 2003].

6 The assay was modified from the published assay to allow the sensitive detection of DNC residues 7 in muscle tissue.

$9 \quad$ Egg and liver assays

10 Homogenised egg or liver test samples $(1 \mathrm{~g})$ were weighed into $30 \mathrm{ml}$ polypropylene tubes. 11 Acetonitrile $(4 \mathrm{ml})$ was added to samples and they were vortexed (10 sec) and sonicated (2 $\mathrm{min})$ 12 prior to centrifugation $(1200 \times g, 10 \mathrm{~min})$. The supernatants were transferred into glass test tubes 13 and evaporated to dryness under a stream of nitrogen at $60^{\circ} \mathrm{C}$. Sample extracts were allowed to $14 \mathrm{cool}$ for $1 \mathrm{~min}$. At this point liver sample extracts were further purified. Liver extracts were 15 reconstituted in cyclohexane $(1 \mathrm{ml})$ by vortexing $(15 \mathrm{sec})$. An aliquot $(250 \mu \mathrm{l})$ of methanol/water $16(75: 25, \mathrm{v} / \mathrm{v})$ was added, the tubes were vortexed $(10 \mathrm{sec})$ and placed in a water bath $\left(37^{\circ} \mathrm{C}, 10\right.$ $17 \mathrm{~min})$ prior to centrifugation $(1200 \times \mathrm{g}, 10 \mathrm{~min})$. Aliquots $(200 \mu \mathrm{l})$ of the aqueous layer were removed 18 and evaporated to dryness under nitrogen.

19 Egg or liver sample extracts were subsequently reconstituted by sequentially adding 20 methanol $(200 \mu \mathrm{l})$ and HBS-EP buffer $(800 \mu \mathrm{l})$, vortexing for $10 \mathrm{sec}$ after each addition. Sample 21 extracts were transferred to eppendorf tubes and centrifuged $(14,000 \times g, 5 \mathrm{~min})$. Sample extracts 22 were further diluted 1:20 (v/v) in HBS-EP buffer prior to analysis on a Biacore ${ }^{\mathrm{TM}} \mathrm{Q}$ system. Aliquots 23 of the extracts $(50 \mu \mathrm{l})$ were mixed with an equal volume of the antibody and injected for 2 min over 24 the sensor chip surface at a flow rate of $25 \mu \mathrm{min}^{-1}$. The response for the sample was determined 25 as the difference in the signal (Response Units, RU) measured before and after injection. The 26 surface was regenerated with a $1 \mathrm{~min}$ pulse of dimethylformamide/180 $\mathrm{mM}$ sodium hydroxide $27(20: 80, v / v)$ at a flow rate of $25 \mu \mathrm{min}^{-1}$. 
2

\section{Muscle assay}

2 A number of modifications of the DNC liver assay were made to allow the detection of low levels of

3 DNC in muscle tissue. Muscle samples $(5 \mathrm{~g})$ were weighed into $30 \mathrm{ml}$ polypropylene tubes and

4 extracted with acetonitrile $(5 \mathrm{ml})$. The supernatants were transferred into glass test tubes and

5 evaporated to dryness under a stream of nitrogen at $60^{\circ} \mathrm{C}$. Sample extracts were allowed to cool

6 for $1 \mathrm{~min}$. Muscle extracts were reconstituted by sequentially adding methanol (200 $\mu \mathrm{l})$ and HBS-

7 EP buffer $(400 \mu \mathrm{l})$ and vortexing for $10 \mathrm{sec}$ after each addition. Reconstituted extracts were further 8 diluted $(1: 1, \mathrm{v} / \mathrm{v})$ with HBS-EP buffer prior to analysis. In a deviation from the liver and egg assays,

9 three additional steps were required to regenerate the chip surface. It was found during the 10 development of the assay to detect low levels of DNC in muscle that there was noticeable carry 11 over of electrostatic nicarbazin residues between injections and a more intensive chip regeneration 12 protocol was required. Chip surfaces were allowed to contact sequentially with (a) $180 \mathrm{mM}$ $13 \mathrm{NaOH} /$ acetonitrile (80:20, v/v), (b) $100 \mathrm{mM} \mathrm{HCl} /$ acetonitrile (80:20, v/v) and (c) $180 \mathrm{mM}$ $14 \mathrm{NaOH} /$ acetonitrile $(80: 20, \mathrm{v} / \mathrm{v})$ at a flow rate of $50 \mu \mathrm{l} \mathrm{min}{ }^{-1}$ for $60 \mathrm{sec}$.

Chemical assays

17 The presence of DNC residues were confirmed by LC-MS/MS [Yakkundi et al. 2001] or by HPLC18 UV [Capurro et al. 2005].

\section{LC-MS/MS assays}

21 Homogenised liver samples $(2.0 \mathrm{~g})$ were weighed into $50 \mathrm{ml}$ polypropylene centrifuge tubes. 22 Internal standard (20 $\mu \mathrm{l}$ of the $10 \mu \mathrm{g} \mathrm{ml}^{-1} \mathrm{~d} 8$-DNC working standard) was added to samples, which $\left.4^{\circ} \mathrm{C}\right)$. An aliquot of the supernatant $(2.5 \mathrm{ml})$ was transferred to glass tubes $(10 \mathrm{ml})$ and evaporated to dryness under nitrogen at $60^{\circ} \mathrm{C}$. After cooling, the residues were reconstituted in hexane $(1 \mathrm{ml})$. This was extracted by vortexing $(10 \mathrm{sec})$ with methanol/water $(75: 25 \mathrm{v} / \mathrm{v}, 250 \mu \mathrm{l})$. The tubes were centrifuged $\left(600 \times g, 10 \mathrm{~min}\right.$ at $\left.4^{\circ} \mathrm{C}\right)$ and an aliquot $(175 \mu \mathrm{l})$ of the aqueous layer was transferred to 
1 microvials for analysis. Calibration curve standard solutions containing DNC and d8-DNC in 2 methanol/water $(75: 25 \mathrm{v} / \mathrm{v})$ were prepared at this time.

A $25 \mu \mathrm{l}$ portion of the final sample extract was injected onto the LC-MS/MS system. The LC-MS/MS system consisted of a Hewlett Packard (Stockport, Cheshire, UK) HPLC system, 31 32 33 34 35 36 comprising an 1100 Series binary pump, autosampler and solvent degasser, was coupled via an electrospray interface to a Quattro LC (Micromass, Wythenshawe, UK), which operated in negative ion mode. The [M-H] ion at $m / z 301$ was monitored along with two transition ions at $m / z 137$ and 107 for DNC and the $[\mathrm{M}-\mathrm{H}]^{-}$ion at $m / z 309$ for the internal standard, d8-DNC. The LC column used was a Luna $5 \mu \mathrm{m} \mathrm{C18} \mathrm{(2)} 250 \times 4.6 \mathrm{~mm}$ (Phenomenex, Macclesfield, Cheshire, UK). The mobile phase, which consisted of $0.05 \mathrm{M}$ ammonium acetate in acetonitrile/water $(75: 25 \mathrm{v} / \mathrm{v})$, was pumped at a rate of $1.0 \mathrm{ml} \mathrm{min}^{-1}$. The column effluent was split so that approximately $100 \mu \mathrm{min}^{-1}$ entered the mass spectrometer. The run time for each injection was 7 min.

Homogenised egg, liver or muscle samples $(2 \mathrm{~g})$ were weighed into $30 \mathrm{ml}$ polypropylene tubes. 16 Fortified egg and liver samples were prepared at levels of 25 and $250 \mu \mathrm{gg}^{-1}$ by adding $50 \mu \mathrm{l}$ 17 portions of 1 and $10 \mathrm{\mu g} \mathrm{ml}^{-1}$ DNC standard solutions to negative control samples, respectively. 18 Fortified muscle samples were prepared at levels of 10 and $100 \mu \mathrm{gg}^{-1}$ by adding $50 \mu \mathrm{l}$ portions of 190.4 and $4 \mathrm{\mu g} \mathrm{ml}^{-1}$ DNC standard solutions to negative control samples, respectively. After 20 fortification, samples were allowed stand for $15 \mathrm{~min}$ prior to extraction. Acetonitrile $(10 \mathrm{ml})$ were 21 added and samples were homogenised using a Polytron ${ }^{\mathrm{TM}}$. The homogeniser probe was washed 22 with acetonitrile $(5 \mathrm{ml})$, which was retained. Samples were vortexed $(2 \mathrm{~min})$, sonicated $(3 \mathrm{~min})$ and shaken $(15 \mathrm{~min})$, before centrifugation $\left(1928 \times \mathrm{g}, 10 \mathrm{~min}, 4^{\circ} \mathrm{C}\right)$. The supernatant was transferred to a clean polypropylene tube and the sample was re-extracted as before using the acetonitrile $(5 \mathrm{ml})$ previously used to wash the homogeniser probe, plus water $(1 \mathrm{ml})$. The supernatants were combined and defatted using hexane $(2 \times 10 \mathrm{ml})$ by vortex mixing, centrifugation and removal of the hexane layer. The acetonitrile layer was evaporated to dryness under nitrogen $\left(60^{\circ} \mathrm{C}\right)$ and 
1 SPE cartridges (preconditioned with $2.5 \mathrm{ml}$ acetonitrile and $2.5 \mathrm{ml}$ acetonitrile/water (70:30, v/v)) 2 and eluted with $2.5 \mathrm{ml}$ acetonitrile/water (70:30, v/v). The eluate from the cartridge was collected in 3 a glass test-tube. Egg and liver extracts were evaporated to dryness under nitrogen $\left(60^{\circ} \mathrm{C}\right)$ and 4 reconstituted in acetonitrile/water (80:20, v/v, $500 \mu \mathrm{l})$. Muscle samples were reconstituted in 5 acetonitrile/water $(80: 20, \mathrm{v} / \mathrm{v}, 200 \mu \mathrm{l})$. Extracts were allowed to sit for $15 \mathrm{~min}$ prior to transfer to 6 HPLC vials; a phase separation may occur in some samples and care was taken not to transfer 7 this lower oily layer into the HPLC vials.

8 A $25 \mu$ l portion of the final sample extract was injected onto the HPLC system. The HPLC 9 system consisted of a model 600 HPLC pump with a model 717 autosampler and model 484 UV 10 detector (set at $350 \mathrm{~nm}$ ), all from Waters (Milford, MA, USA). The separation was carried out on a 11 stainless-steel analytical column $(250 \times 4.6 \mathrm{~mm}$ i.d $)$ equipped with a Securiguard ${ }^{\mathrm{TM}}$ pre-column, 12 both packed with Hypersil BDS $\mathrm{C}_{18}$ material (Phenomenex, Cheshire, UK). The column 13 temperature was maintained at $40^{\circ} \mathrm{C}$. The mobile phase, consisting of water/acetonitrile $(55: 45$, $14 \mathrm{v} / \mathrm{v})$, was pumped at $1 \mathrm{ml} / \mathrm{min}$. Under these conditions the retention time of DNC was 15 approximately $13 \mathrm{~min}$. A Waters 746 data processing module was used for recording and 16 processing chromatograms.

\section{Calibration}

Biacore

21 Standards were prepared by fortifying negative control egg and liver samples at concentrations of $220,50,100,250,500$ and $1000 \mu \mathrm{g} \mathrm{kg}^{-1}$ and muscle at concentrations of $0,1,2.5,5,10,25$ and 50 $23 \mu \mathrm{gg}^{-1}$ of DNC for calibration. Calibration curves were prepared by plotting response as a function 24 of DNC concentration $\left(\mu \mathrm{g} \mathrm{kg}^{-1}\right)$. The DNC concentration in test samples was read directly from the 25 calibration curve prepared from fortified samples that were run with that particular batch. 


\section{LC-MS/MS}

2 Calibration curve standard solutions containing DNC and d-8 DNC were prepared in 3 methanol/water (75:25 v/v). The DNC standards were prepared at the concentration 0, 100, 200, 4300,400 and $500 \mu \mathrm{g} \mathrm{kg}^{-1}$ standard equivalent along with known equal amount of internal standard 5 d-8 DNC. The calibration curve was obtained by plotting the standard concentrations against the 6 peak area ratios of d-8 DNC and DNC. The DNC concentration in unknown samples was reported 7 as internal standard corrected value.

$9 \quad H P L C$

10 Standards were prepared at concentrations of $0,50,100,250,500,1000$ and $2000 \mathrm{ng} \mathrm{ml}^{-1} \mathrm{in}$ 11 acetonitrile/water (80:20, v/v). Calibration curves were prepared by plotting peak area as a function 12 of DNC concentration (ng ml${ }^{-1}$ ). The DNC concentration in test samples was determined from the 13 peak areas obtained for test sample extracts, as calculated from the calibration curve. The DNC 14 concentration in test samples was reported corrected for recovery using recovery factors 15 calculated from fortified samples that were run with that particular batch.

\section{$17 \quad$ Validation of methods}

18 The methods used in this comparison were validated according to current EU guidelines as 19 described in Commission Decision 2002/657/EC. The assays were validated to allow detection or 20 determination of DNC to an MRL of $200 \mathrm{\mu g} \mathrm{kg}^{-1}$. The sensitivity of the Biacore ${ }^{\mathrm{TM}}$ biosensor, HPLC21 UV and LC-MS/MS assays are much lower than the MRL. Limits of determination of DNC are 33.2, 2212.5 and $10 \mu \mathrm{g} \mathrm{kg}^{-1}$ in liver; 34.8, 12.5 and $10 \mu \mathrm{g} \mathrm{kg}^{-1}$ in egg; and 5, 5 and $2 \mu \mathrm{g} \mathrm{kg}^{-1}$ in muscle, 23 respectively.

Industry surveys

Broiler liver survey 
1 Liver samples $(n=736)$ were taken from 16 poultry companies (coded $A$ to $P$ ), which were 2 representative of over $95 \%$ of domestic broiler production on the island of Ireland. In 2002 , 3 samples were collected from companies A to $\mathrm{H}$ between March and November; no samples were 4 taken during May. The majority of the 238 samples were collected during the months of September $5 \quad(n=52)$, October $(n=89)$ and November $(n=81)$. In 2003, samples were collected from 6 companies $\mathrm{A}$ to $\mathrm{H}$ between February and November. The lowest and highest number of samples 7 were taken during the months of June $(n=7)$ and April $(n=46)$, respectively. Samples were 8 collected from companies I to P between May 2002 and April 2003. A total of 265 samples were 9 collected and the monthly sampling numbers are described in Figure 2. Samples were screened 10 using the immunobiosensor assay and samples found to contain DNC at levels greater than $33 \mu \mathrm{g}$ $11 \mathrm{~kg}^{-1}$ were selected for confirmatory analysis.

\section{Broiler muscle survey}

14 Breast meat samples $(n=342)$ were taken from 13 poultry companies. Three of the companies 15 involved in the liver survey $(A, G$ and $H)$ did not participate in this study. Samples were collected 16 from companies $B$ to $F(n=127)$ between July and December 2003. A total of 215 samples were collected from companies I to P between May 2003 and April 2004 at a frequency of 16 to 21 18 samples per month. Samples were screened using the immunobiosensor assay and samples 19 found to contain DNC at levels greater than $5 \mathrm{\mu g} \mathrm{kg}^{-1}$ were selected for confirmatory analysis.

21 Egg survey

22 Egg samples $(n=546)$ were taken by official agriculture inspectors from egg packers, 23 representative of small, medium and large egg producers on the island of Ireland between 2003 24 and 2004. Samples were screened by the immunobiosensor assay and samples found to contain 25 DNC at levels greater than $12.5 \mathrm{\mu g} \mathrm{kg}^{-1}$ were selected for confirmatory analysis. During sample screening, it was found that the immunobiosensor could detect DNC residues in egg samples at $27<12.5 \mu \mathrm{g} \mathrm{kg}^{-1}$. 
Imported breast muscle survey

2 A survey of imported broiler breast muscle was undertaken in the period 2003 to 2004 . In total, 217 3 samples of imported breast muscle were obtained from retail outlets, from Environmental Health 4 Officers carrying out inspections at food premises, by official agriculture inspectors at border 5 inspection posts and meat processing companies. Samples were screened using the 6 immunobiosensor assay and samples found to contain DNC at levels greater than $5 \mu \mathrm{kg}^{-1}$ were 7 selected for confirmatory analysis.

9 Confirmatory analyses

10 Samples from all surveys screened as containing DNC residues were confirmed by an 11 independent chemical assay (HPLC-UV or LC-MS/MS). HPLC-UV has been described as suitable 12 for confirming the presence of Group B substances, when used in conjunction with a second 13 independent detection assay (Anon. 2002). In this survey, an immunobiosensor was used as the 14 second independent detection assay.

Results and discussion

17 Liver survey

18 An overall summary of the poultry liver survey is presented in Figure 1. The survey showed that 12 19 and $3 \%$ of samples contained DNC residues at $>200$ and $>1000 \mu \mathrm{g} \mathrm{kg}^{-1}$, respectively. DNC 20 residues were found at $<200 \mu \mathrm{g} \mathrm{kg}^{-1}$ in $28 \%$ of samples and no residues were detectable (i.e. not 21 detected above $33 \mu \mathrm{kg} \mathrm{kg}^{-1}$ by immunobiosensor and/or confirmed above $12.5 \mu \mathrm{g} \mathrm{kg}^{-1}$ using 22 chemical assays) in $60 \%$ of samples.

24 Seasonal variation in levels of DNC in liver

25 The seasonal variation in DNC levels in broiler liver samples from eight companies ( $I$ to $P$ ) is 26 shown in Figure 2. In general, there was a similarity in the proportion of samples containing DNC 59 and of samples containing DNC at $>200 \mu \mathrm{g} \mathrm{kg}^{-1}$ over time. In the period June to August the

28 incidence of DNC containing liver samples was lower by a factor of at least twofold compared to 
1 other months. A number of hypotheses may be proposed for the lower incidence of DNC residues

2 in poultry during the June to August period. One hypothesis is that reduced usage of nicarbazin 3 may have occurred during the summer months; nicarbazin can cause heat stress, resulting in 4 increased mortality in broilers during warm weather. A second hypothesis is that the lower 5 incidence of DNC residues may be related to the removal of licensing for products containing 6 nicarbazin alone that occurred in May 2002. A third hypothesis is that the higher incidence of DNC 7 residues in broiler liver from September onwards may have been due to changes in the feeding 8 programmes used on poultry farms, with nicarbazin-containing feed being given to birds closer to 9 slaughter time.

11 Variation in DNC levels in liver sampled from different companies

12 The breakdown by company of samples containing DNC residues and containing DNC residues $13>200 \mu \mathrm{g} \mathrm{kg}^{-1}$ is shown in Table I. For two companies ( $\mathrm{F}$ and $\mathrm{G}$ ) no samples containing DNC 14 residues were found; however, few samples were sourced from these companies during the 15 survey. The percentages of samples containing DNC residues range between 15 and $84 \%$ for the 16 other companies. The mean value for 16 companies was $42 \%$ of samples contained DNC 17 residues. The mean result for companies containing DNC residues $>200 \mu \mathrm{g} \mathrm{kg}^{-1}$ was $14 \%$, with the 18 lowest at $0 \%$ and the highest at $42 \%$. Three companies, $C, E$ and $L$ had 10,22 and $33 \%$ of 19 samples containing DNC residues but 0,0 and $1 \%$ of samples from these companies contained 20 DNC residues $>200 \mu \mathrm{g} \mathrm{kg}^{-1}$, respectively. Companies $\mathrm{M}$ and $\mathrm{N}$ had less than $10 \%$ of samples 21 containing DNC $>200 \mu \mathrm{gg}^{-1}$.

\section{Survey of breast meat}

24 A total of 342 samples of broiler breast meat (muscle) were tested for DNC residues. The overall 25 breakdown of results is shown in Figure 3. DNC residues were determined in $26 \%$ of samples at 26 levels ranging between 5 and $183 \mu_{\mathrm{g} \mathrm{kg}}{ }^{-1}$. No residues were detected in $74 \%$ of muscle samples. 59 No muscle sample contained DNC residues above $200 \mu \mathrm{g} \mathrm{kg}^{-1}$. A lower percentage of muscle samples contained measurable DNC residues compared to liver samples. A lower incidence of 
1 DNC-positive muscle, compared with liver, is supported by the pharmacokinetic profiles, which 2 show that DNC residues occur at higher concentrations in liver compared to muscle [Anon. 1999]. 3 As a result, DNC residues may be detected for a longer period of time in liver and the probability of 4 finding DNC residues in tissue is lower for muscle than for liver. The results for the muscle and 5 liver surveys indicate that liver is the most appropriate matrix to use for monitoring DNC residues 6 because it is the matrix in which residues persist at highest concentrations.

\section{Seasonal variation in levels of DNC in muscle}

9 The seasonal variation for DNC residues in breast meat is shown in Figure 4. The average monthly 10 incidence of muscle samples containing DNC is $20 \%$. The highest incidence occurred in the 11 months of May, November and March with 28, 28 and $42 \%$ of muscle samples containing DNC 12 residues, respectively. The proportion of liver samples likely to contain DNC at levels $>200 \mu \mathrm{kg}^{-1}$ 13 was estimated from the muscle survey results. A level of approximately $7 \mu \mathrm{g} \mathrm{kg}^{-1} \mathrm{DNC}$ in muscle 14 has been estimated as equivalent to approximately $200 \mu \mathrm{g} \mathrm{kg}^{-1}$ in liver tissue. This approximation 15 is derived from the mean values obtained for a comparison of DNC residues in liver and muscle for 16 birds raised in deep litter $\left(9.0 \mu \mathrm{g} \mathrm{kg}^{-1}\right.$ muscle $\approx 200 \mu \mathrm{g} \mathrm{kg}^{-1}$ liver $)$ and those on wire flooring $(5.5 \mu \mathrm{g}$ $17 \mathrm{~kg}^{-1}$ muscle $\approx 200 \mu \mathrm{g} \mathrm{kg}^{-1}$ liver) [Cannavan and Kennedy 2000]. Using this estimation, the 18 percentage of liver samples likely to contain DNC at $>200 \mu \mathrm{g} \mathrm{kg}^{-1}$ was calculated (Figure 4); the 19 estimated incidence of liver samples containing $>200 \mu \mathrm{g} \mathrm{kg}^{-1} \mathrm{DNC}$ was similar to that observed for 20 the liver survey, with a mean value of $14 \%$ (Table I).

Variation in DNC levels in muscle sampled from different companies

23 The breakdown by company of muscle samples containing DNC residues and corresponding liver 24 samples (estimated as containing DNC residues $>200 \mu \mathrm{g} \mathrm{kg}^{-1}$ ) is shown in Table I. No samples 25 from companies $\mathrm{E}$ and $\mathrm{F}$ contained measurable DNC residues and company $\mathrm{C}$ had only $3 \%$ of samples containing measurable DNC residues. For the other companies, the proportion of muscle samples containing measurable DNC ranged between 20 and $50 \%$. A comparison between the liver survey (2002/03) and estimated liver survey (2003/04) shows that for some companies (B, I, 
$1 \mathrm{~J}, \mathrm{~L}$ and M) there was a higher incidence of DNC residues at $>200 \mathrm{\mu g} \mathrm{kg}^{-1}$ in the second survey, 2 while for companies $\mathrm{K}, \mathrm{N}, \mathrm{O}$ and $\mathrm{P}$ however a lower incidence in liver may be concluded from the 3 muscle survey (Table I). Companies $C$ and $D$ showed no appreciable change in incidence between 4 the two surveys.

5 The proportion of liver samples containing DNC residues $>200 \mu \mathrm{g} \mathrm{kg}^{-1}$ (determined for 6 2002/03 and estimated for 2003/04) may vary between companies and within companies from year 7 to year. The results of the surveys show that DNC residues in broilers occur throughout the year 8 and that flocks require frequent sampling (such as each month), proportional to scale of 9 production, to identify the situation.

11 Imported breast muscle

12 A total of 217 samples of imported breast meat were sampled over the period May 2003 to 13 September 2004. The objective of the survey was to make a comparison between DNC residues in 14 domestic and imported poultry meat consumed on the island of Ireland. The results of the survey 15 are shown in Table II. Samples were sourced from wholesalers, meat processing companies, 16 border inspection posts and retail outlets. The imported breast meat samples originated from 11 17 different countries. DNC residues were determined in 13 samples at levels ranging from 2.7 to 18.7 $18 \mu \mathrm{g} \mathrm{kg}^{-1}$. The results of the survey indicate that DNC residues were at a lower level in imported 19 meat $(6 \%)$ compared to domestic meat samples $(26 \%)$. Samples from only three countries had 20 measurable DNC residues (France, Thailand and The Netherlands). The relatively low number of 21 positives for DNC in imported meat suggests (a) that alternative anticoccidial agents may be used 22 in other countries and/or (b) practices are adopted at feed mills and on farms that allow better 23 control of DNC residues in poultry production.

\section{Survey of eggs}

A survey of table eggs was carried out during 2003 to 2004 . A total of 546 egg samples were collected and DNC residues were determined in nine samples. No residues were detectable (i.e. not detected above $34.8 \mu \mathrm{g} \mathrm{kg}^{-1}$ by immunobiosensor and/or confirmed above $12.5 \mu \mathrm{g} \mathrm{kg}^{-1}$ using 
1 chemical assays) in $98 \%$ of egg samples. The levels of DNC residues present ranged between 14 2 and $122 \mu \mathrm{g} \mathrm{kg}^{-1}$. DNC residues occurred in egg samples throughout the year. The contaminated 3 egg samples were sourced from four companies and one of these companies had five positive 4 samples. Nicarbazin is not approved for the treatment of layer hens and residues in eggs may be 5 attributed to contamination of layer feed with low levels of nicarbazin [Cannavan et al. 2000]. DNC 6 residues may be eliminated from eggs through adequate quality control of feed samples shipped to 7 farms.

Performance of the biosensor screening assay for detection of nicarbazin residues

10 Connolly et al. (2003) characterised the antibody applied in this assay. The antibody was shown to 11 be specific towards DNC and did not cross-react to other potential interfering substances namely, 12 the anti-coccidials, toltrazuril, halofuginone and ronidazole. In routine application, it has been found 13 that the antibody does not cross-react to lasalocid and other ionophore (monensin, salinomycin 14 and narasin) residues detected in egg and liver samples. The cut-offs for sending samples for 15 confirmatory analysis was determined through the analysis of 20 negative liver and 20 known 16 negative egg samples. Briefly, analysis of 20 known negative livers yielded values of $1.19 \pm 5.32$ $17 \mu \mathrm{g} \mathrm{kg}^{-1}$. The limits of detection (mean +3 S.D.) and determination (mean +6 S.D.) were calculated 18 as 17.1 and $33.2 \mu \mathrm{gg}^{-1}$, respectively. A second validation study was carried out in eggs and 19 analysis of 20 known negative eggs yielded values of $3.07 \pm 5.29 \mu \mathrm{g} \mathrm{kg}^{-1}$. The limits of detection 20 and determination were calculated as 18.9 and $34.8 \mu \mathrm{g} \mathrm{kg}^{-1}$, respectively. A more comprehensive 21 evaluation of the suitability of the limits of determination was carried out during the egg and liver 22 surveys. A total of 145 samples confirmed to contain DNC residues by HPLC were also screened 49 
1 The results for DNC residues in poultry liver and eggs samples between 2002 and 2005 indicate 2 that the percentage of liver samples containing DNC at levels $\geq 200 \mu \mathrm{g} / \mathrm{kg}$ decreased to $7 \%$ in 2005 3 (O'Keeffe et al. 2005; O'Keeffe et al. 2006). This was a 50\% reduction in positives from the 4 previous three years even though the useage of Maxiban throughout Ireland had increased. The 5 results of official food inspection for 2006 will provide a clearer indication if this reduction in DNC 6 positives is sustainable or just a brief improvement. The reduction in DNC positives can be largely 7 attributed to on-farm investigations, which were carried out with the aim of identifying the cause of 8 DNC residues during 2004 to 2005 (O'Keeffe et al. 2007). In addition, there has been increased 9 scrutiny placed on the control of DNC residues by regulatory agencies. As a result, a number of 10

\section{Conclusions}

DNC is a frequent contaminant of poultry products on the island of Ireland and has been shown to

be a contaminant both of liver and breast meat. Residues may also occur in eggs but are typically at less than $2 \%$ of samples. Residues in eggs may be largely attributed to contaminated feed because administration of nicarbazin to layers is not approved because it affects bird fertility and egg shells. DNC residues occur in poultry samples throughout the year, indicating that this anticoccidial needs to be monitored continuously in poultry. Residues in liver and meat can be caused by a number of different factors, but may be attributed mainly as due to improper feed management on farms and at feed mills (O'Keeffe et al. 2007). The number of liver samples exceeding the MRL of $200 \mu \mathrm{g} \mathrm{kg}^{-1}$ DNC may vary considerably within individual companies between years. In 2005, there was a reduction in the number of broiler liver samples containing DNC at $>200 \mu \mathrm{g} \mathrm{kg}^{-1}$, to approximately $7 \%$ of samples tested in the monitoring programmes (O'Keeffe et al. 2006, Shortt 2006). The available results from official food inspections for 2006 indicate a similar lower proportion of samples containing DNC residues at levels $>200 \mu \mathrm{g} \mathrm{kg}^{-1}$. The reduction in DNC positives may be attributed partly to on-farm investigations, which were carried 
1 out during 2004/05 with the aim of identifying the causes for DNC residues in poultry (O'Keeffe et

2 al. 2007). In addition, there has been increased scrutiny on the control of DNC residues in poultry 3 by regulatory authorities and a number of companies have instigated there own testing 4 programmes to fulfil self-monitoring as required by EU food law (96/23/EC).

5

6

7 References

8 Anon., 1999, Freedom of information summary - Combined use of MAXIBAN and BMD in Chicken

9 Feeds Approval Date: January 41999 (http://www.fda.gov/cvm/efoi/section2/140-926.pdf, 10 accessed 3/11/2004).

Anon., 2001, Official Journal of the European- Commission Regulation No. 2205/2001/EC. No. L 297/3.

Anon., 2002, Official Journal of the European- Commission Regulation No. 657/2002/EC. No. L $221 / 8$.

Anon., 2007, Community Register of Feed Additives pursuant to Regulation (EC) No 1831/2003

Appendixes 3 \& 4. Annex : List of additives Rev. 16 (June 2007).

Cannavan, A. and Kennedy, D.G., 2000, Possible causes of nicarbazin residues in chicken tissues. Food Additives and Contaminants, 17, 1001-1006.

Cannavan, A., Ball, G. and Kennedy, D.G., 2000, Nicarbazin contamination in feeds as a cause of residues in eggs. Food Additives and Contaminants, 17, 829-836.

Capurro, E., Danaher, M., Anastasio, A., Cortesi M. L. and O'Keeffe, M., 2005, Efficient HPLC method for the determination of nicarbazin, as dinitrocarbanilide, in broiler liver. Journal of Chromatography B, 822, 154 - 159. 


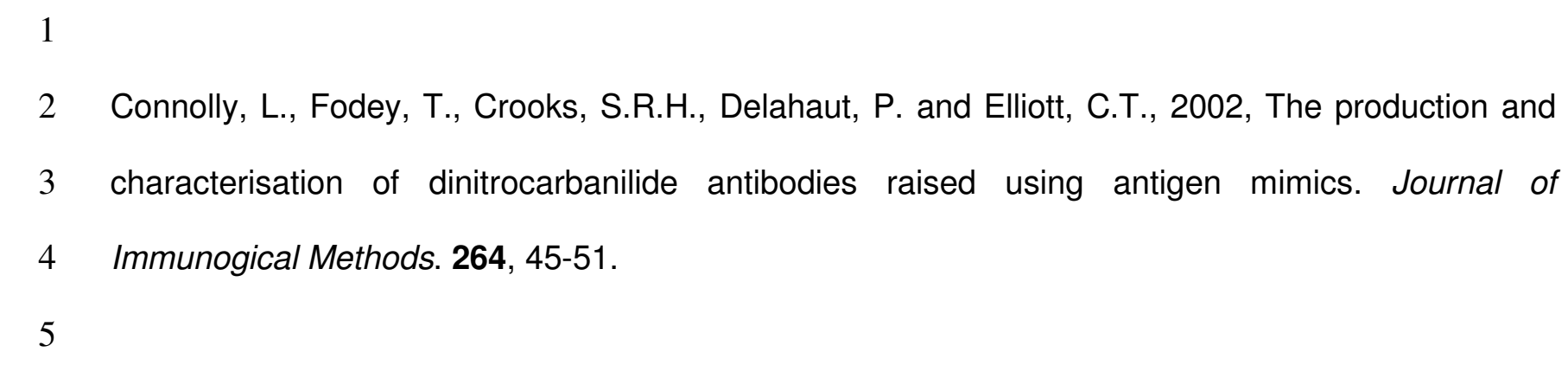

2 Connolly, L., Fodey, T., Crooks, S.R.H., Delahaut, P. and Elliott, C.T., 2002, The production and 3 characterisation of dinitrocarbanilide antibodies raised using antigen mimics. Journal of 4 Immunogical Methods. 264, 45-51. 5

6 De Giovanni, F., Amendola, F., and Cortesi, M.L., 1989, Residui di nicarbazina in uova del 7 marcato. Industrie Alimentari, 28, 10-13.

9 Gallo, P., Serpe, L, 1997, Monitorie dei Residui Di Nicarbazina in Matricia do originie animale 10 biennio 1994-1996. Industrie Alimentari, 6,18 - 620.

McCarney, B., Traynor, I. M., Fodey, T.L., Crooks, S. R. H., Elliott, C.T., 2003, Surface Plasmon resonance biosensor screening of poultry liver and eggs for nicarbazin residues. Analytica Chimica 14 Acta. 483, 165-169.

McEvoy, J.D.G., Smyth, W.G. and Kennedy, D.G., 2003, Contamination of animal feedingstuffs with nicarbazin: investigations in a feed mill. Food Additives and Contaminants, 20, 136-140.

Oishi, Y., and Oda, T., 1989, Studies on residues of nicarabazin in eggs of laying hens. Shokuhon Eiseigaku Zasshi, 30, 542-547.

O'Keeffe, M. and Coen, K., 2005. National Food Residue Database Report 2005, Teagasc, Dublin, ISBN: $1841703974,57 \mathrm{pp}$.

O'Keeffe, M., Rehmann, F.J. and Coen, K., 2006. National Food Residue Database Report 2006, Teagasc, Dublin, ISBN: 184170462 3, 60 pp. 
1 O'Keeffe, M., Capurro, E., Danaher, M., Campbell, K, Elliott, C.T., 2007. Investigation of the

2 causes for occurrence of residues of the anticoccidial feed additive nicarbazin in commercial

3 poultry. Food Additives and Contaminants, in press.

4

5 Penz, A.M.Jr., Vieira, S.L. and Ludke, J.V., 1999, Nicarbazin residues in broiler tissue and litter.

6 Journal of Applied Poultry Science, 8, 292-297.

8 Porter, C.C.; Gilfillan, J.L. The absorption and excretion of orally administered nicarbazin by 9 chickens. Poultry Sci., 1955, 34, 995-1001.

11 Shortt, D. Personal Communication 2006.

Vertommen, M.H., Van Der Laan, A., Veenedaal-Hesselman, H.M., 1989, High performance liquid 14 chromatographic screening method for low levels of Nicarbazin in eggs with off-line cartridge 15 sample clean-up. Journal of Chromatography, 481, 452-457.

Veterinary Residues Committee, 2006. Annual Report on Surveillance for Veterinary Residues in 18 Food in the UK 2005, Veterinary Residues Committee, Surrey, UK, 48 pp.

Wells, R.J., 1999, Wells, Nicarbazin. In FAO Food and Nutrition Paper 41/11, Food

21 and Agriculture Organisation of the UN, Rome, 83-93.

Yakkundi, S, Cannavan, A., Elliott, C.T., Lovgren, T., Kennedy, D.G., 2001, Development and validation of a method for the confirmation of nicarbazin in chicken liver and eggs using LCelectrospray MS-MS according to the revised EU criteria for veterinary drug residue analysis. 26 Analyst. 126, 1985-1989. 
21 Acknowledgements

3

2 The authors would like to acknowledge safefood, the Food Safety Promotion Board, for funding 3 this project. The authors would also like to acknowledge the assistance of Agriculture Inspectors 4 and Environmental Health Officers for their assistance in collecting samples. Mr. Cedric Bourgeon $5 \quad$ is acknowledged for carrying out analysis of ionophore residues in muscle samples.

6 
Table I Variation in the percentage of liver and muscle samples containing DNC residues that were surveyed from companies $A$ to $P$

\begin{tabular}{|c|c|c|c|c|}
\hline \multirow[b]{2}{*}{ Company } & \multicolumn{2}{|c|}{ Liver Survey $(\mathrm{n}=736)$} & \multicolumn{2}{|c|}{ Domestic Muscle Survey $(\mathrm{n}=342)$} \\
\hline & $\begin{array}{c}\text { Samples } \\
\text { containing } \\
\text { DNC } \geq 12.5 \mu \mathrm{g} \\
\mathrm{kg}^{-1}(\%) \\
\end{array}$ & $\begin{array}{c}\text { Samples } \\
\text { containing DNC } \\
\geq 200 \mu \mathrm{g} \mathrm{kg}^{-1} \\
(\%)\end{array}$ & $\begin{array}{c}\text { Samples containing } \\
\text { DNC } \geq 5 \mu \mathrm{g} \mathrm{kg}^{-1} \\
(\%)\end{array}$ & $\begin{array}{c}\text { Estimate of liver } \\
\text { samples containing } \\
\text { DNC } \geq 200 \mu \mathrm{g} \mathrm{kg}^{-1} \\
(\%)\end{array}$ \\
\hline A & 84 & 26 & - & - \\
\hline B & 47 & 16 & 38 & 29 \\
\hline $\mathrm{C}$ & 15 & 1 & 3 & 0 \\
\hline $\mathrm{D}$ & 41 & 13 & 36 & 14 \\
\hline $\mathrm{E}$ & 22 & 0 & 0 & 0 \\
\hline $\mathrm{F}$ & 0 & 0 & 0 & 0 \\
\hline $\mathrm{G}$ & 0 & 0 & - & - \\
\hline $\mathrm{H}$ & 40 & 33 & - & - \\
\hline I & 46 & 11 & 36 & 17 \\
\hline $\mathrm{J}$ & 67 & 25 & 30 & 33 \\
\hline K & 83 & 25 & 22 & 9 \\
\hline $\mathrm{L}$ & 33 & 0 & 27 & 25 \\
\hline M & 25 & 6 & 20 & 17 \\
\hline $\mathrm{N}$ & 44 & 8 & 20 & 3 \\
\hline $\mathrm{O}$ & 63 & 42 & 50 & 29 \\
\hline $\mathrm{P}$ & 59 & 16 & 20 & 8 \\
\hline Mean & 42 & 14 & 23 & 14 \\
\hline
\end{tabular}


Table II The incidence of DNC residues in breast muscle samples imported into the island of Ireland

\begin{tabular}{|c|c|c|}
\hline Country & Number of samples tested & $\begin{array}{c}\text { Number of samples } \\
\text { containing DNC at } \\
>5 \mu \mathrm{g} / \mathrm{kg}\end{array}$ \\
\hline The Netherlands & 68 & 4 \\
\hline Denmark & 26 & 0 \\
\hline Belgium & 7 & 0 \\
\hline France & 10 & 8 \\
\hline Brazil & 58 & 0 \\
\hline Chile & 2 & 0 \\
\hline Germany & 14 & 0 \\
\hline Thailand & 22 & 1 \\
\hline Romania & 5 & 0 \\
\hline New Zealand & 8 & 0 \\
\hline UK & 1 & 0 \\
\hline
\end{tabular}




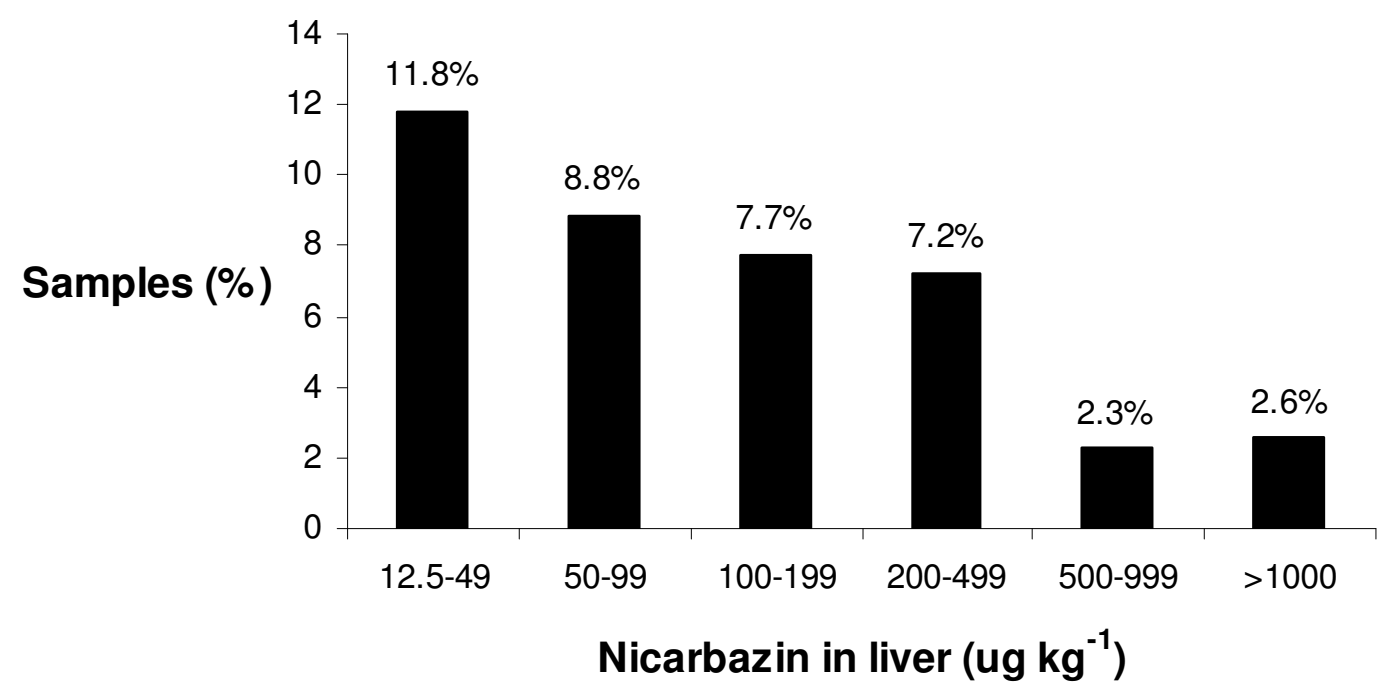

Figure 1 Levels of DNC residues in broiler liver samples $(n=736)$ 


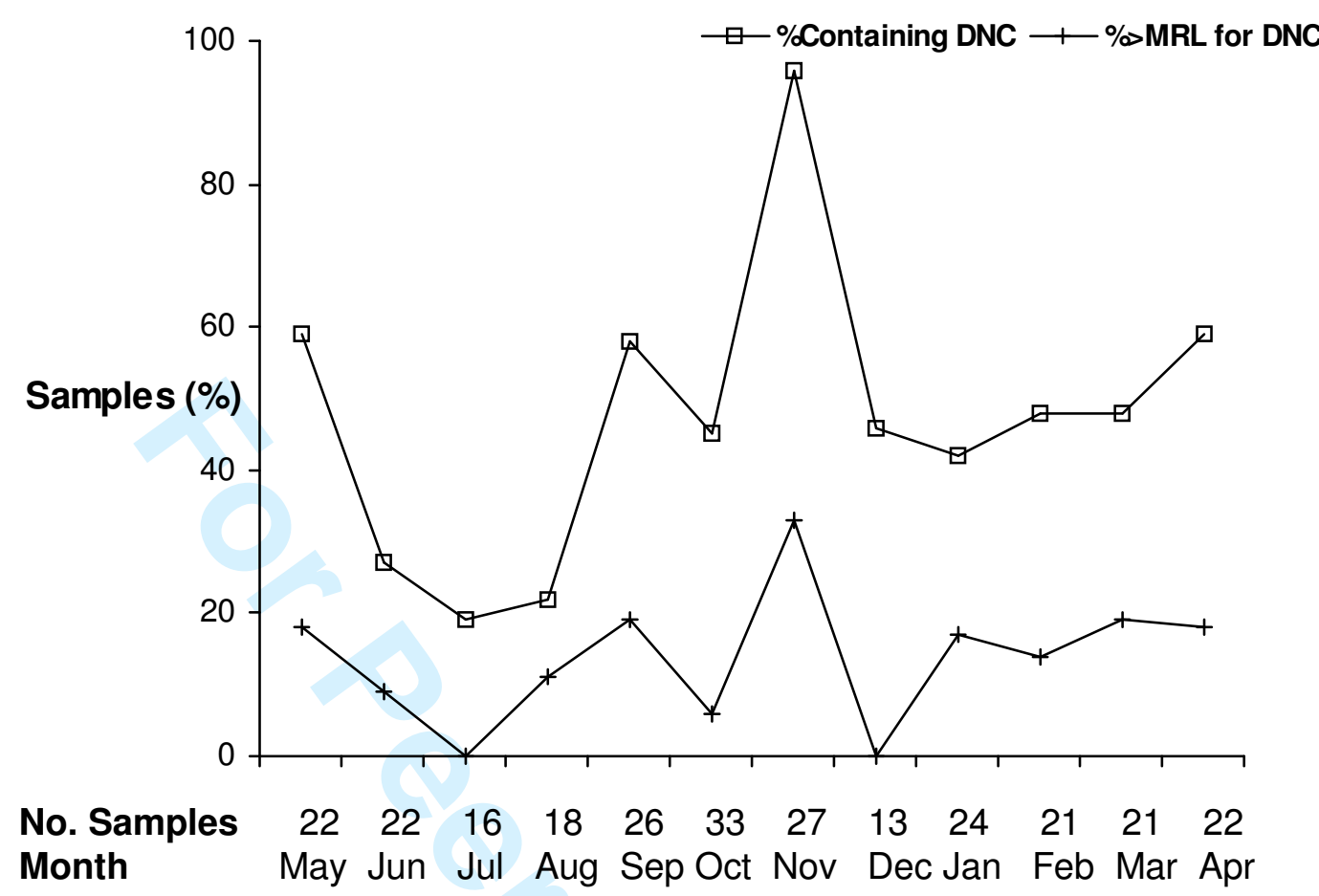

Figure 2 Seasonal variation of DNC residues in broiler liver samples, May 2002 to April 2003 (companies I to P) 


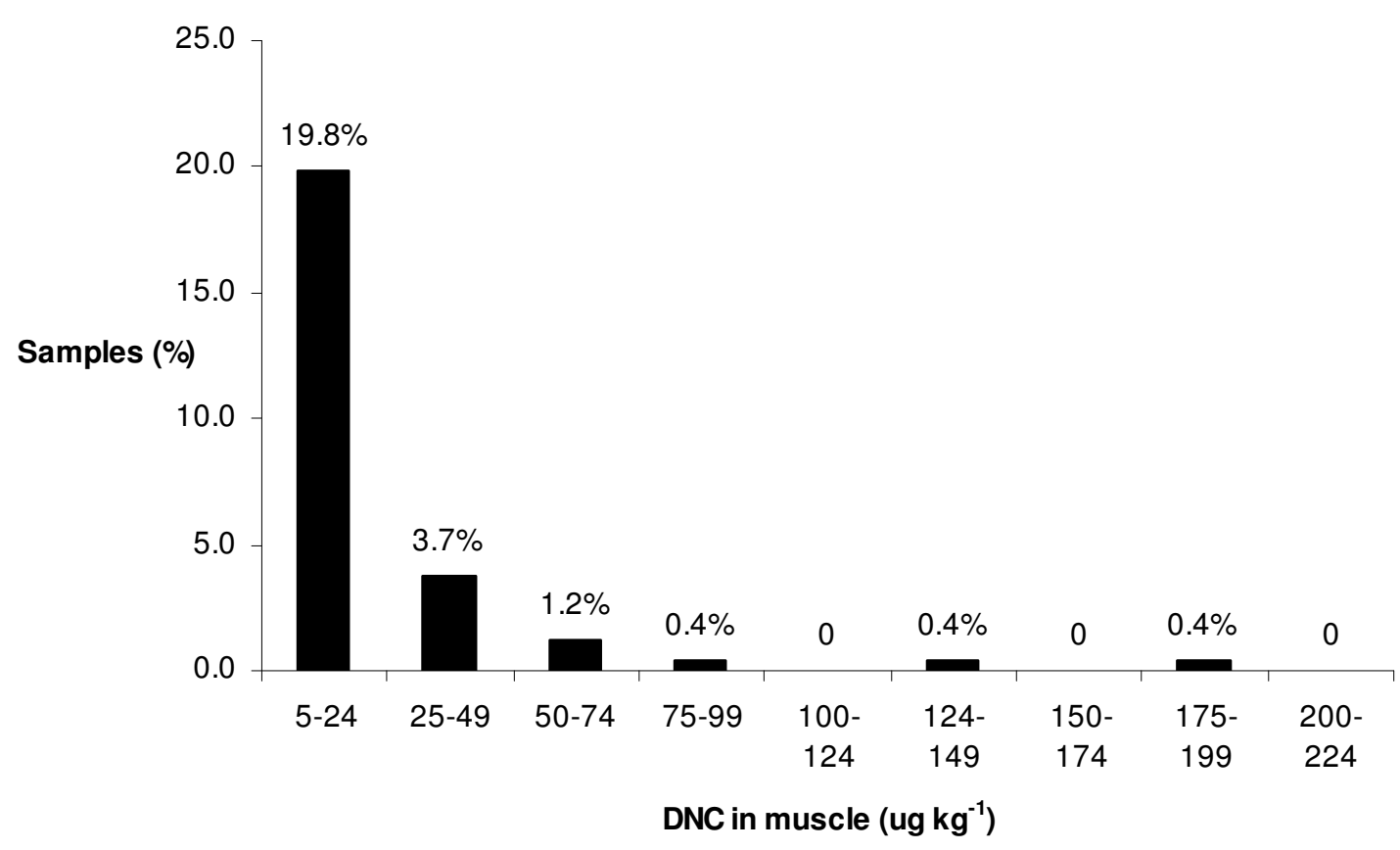

Figure 3 Distribution of DNC residues in broiler breast samples $(n=342)$ 


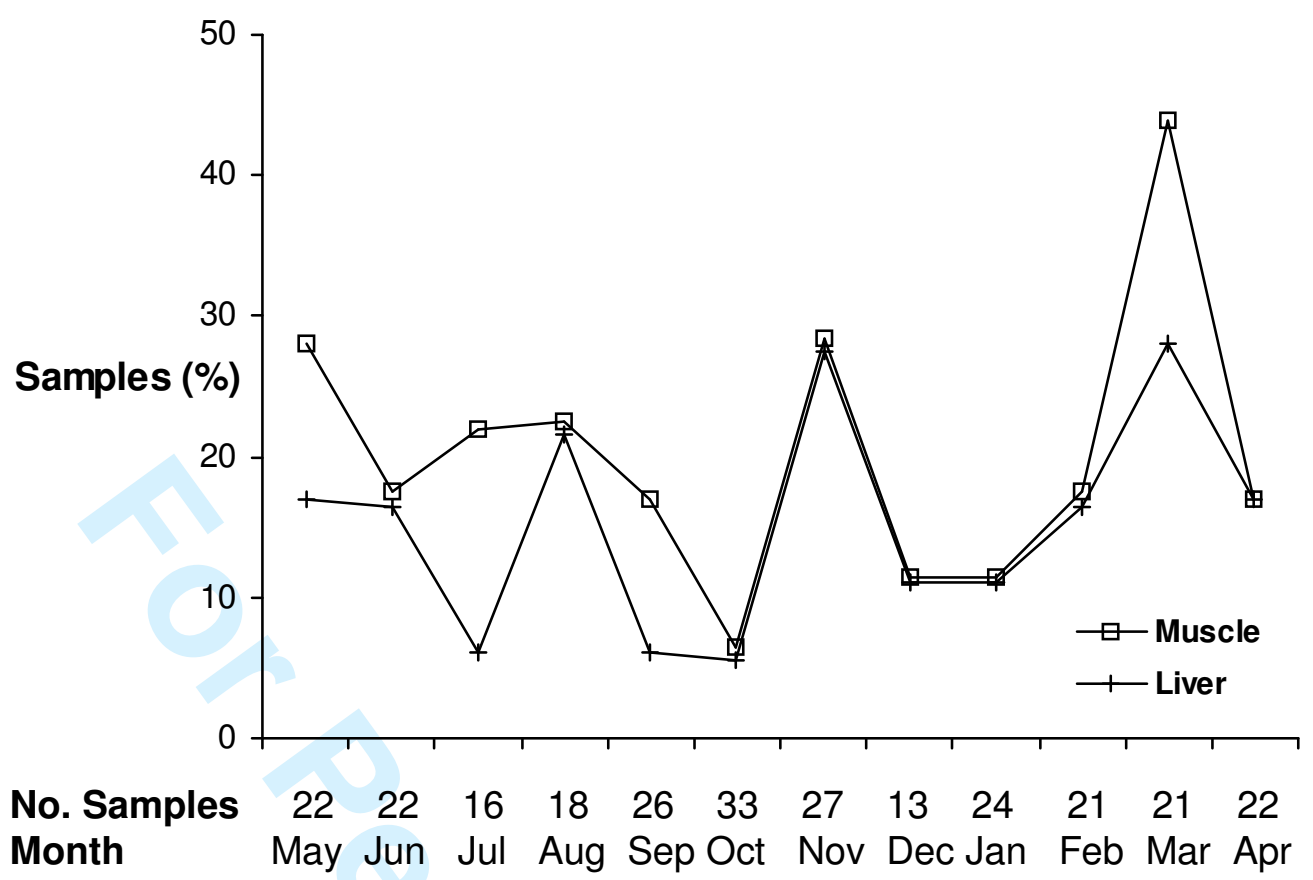

Figure 4 Seasonal variation of DNC residues in poultry breast muscle and estimation of percentage of liver samples containing >200 $\mu \mathrm{g} / \mathrm{kg}$ DNC, May 2003 to April 2004 (companies I to $P$ ) 